IJMS 17 (2), 105-120 (2010)

\title{
TEACHERS' ENGAGEMENT IN WORKPLACE LEARNING ACTIVITIES: VALIDATION OF A MEASURE
}

\author{
TENGKU FAEKAH TENGKU ARIFFIN \\ ROSNA AWANG HASHIM \\ UUM College of Arts and Sciences \\ Universiti Utara Malaysia
}

\begin{abstract}
Quantitative research into the topic of workplace learning among teachers has been limited due to the lack of measures that are applicable to the educational settings. In this study, items measuring teachers' engagement in workplace learning activities were generated through literature review and discussions with schoolteachers; selected by the authors; and then tested in a field study. The sample involved a total of 500 schoolteachers, selected through a multistage cluster sampling procedure. Exploratory and confirmatory factor analyses were used to test the hypothesised two-dimensional model for the construct of engagement in workplace learning activities. Results indicated that the proposed model acceptably fits the data and the loadings were all significant at $p<.05$, thus lending evidence for the construct validity of the instrument. Implications for the use of this scale in future workplace learning research, particularly in the educational settings, are discussed.
\end{abstract}

Keywords: Instrument validation; schoolteachers; workplace learning.

\begin{abstract}
Abstrak
Kajian kuantitatif terhadap topik pembelajaran di tempat kerja dalam kalangan guru-guru amat terhad disebabkan oleh kekurangan instrumen yang boleh diaplikasikan dalam konteks pendidikan. Dalam kajian ini, item-item yang digunakan bagi mengukur penyertaan guru dalam aktivitiaktiviti pembelajaran di tempat kerja dihasilkan melalui sorotan karya dan perbincangan dengan guru-guru sekolah; dipilih oleh penulis; dan kemudian diuji dalam kajian lapangan. Sampel melibatkan 500 orang guru sekolah di utara Malaysia, yang dipilih melalui persampelan kluster secaraberperingkat. Analisis faktor eksploratori dan konfirmatori digunakan bagi menguji model dwidimensi yang dicadangkan bagi konstruk penyertaan dalam aktiviti-
\end{abstract}


aktiviti pembelajaran di tempat kerja. Hasil kajian menunjukkan bahawa model yang dicadangkan sesuai dengan data yang dikumpul dan kesemua nilai muatan faktor yang signifikan pada p<.05, membuktikan kesahan konstruk bagi instrumen yang digunakan. Implikasi terhadap penggunaan instrumen ini dalam kajian pada masa akan datang yang berkaitan dengan pembelajaran di tempat kerja terutamanya dalam konteks pendidikan turut dibincangkan.

Kata kunci: Kesahan instrument; guru sekolah; pembelajaran di tempat kerja.

\section{Introduction}

Workplace learning is a concept related to learning organisation and organisational learning alike, which receives a lot of attention among scholars in the organisational field, human resources, and adult education. The reason for highlighting workplace learning is because it has emerged as becoming increasingly important to enable employees to sustain their knowledge and keep themselves up-to-date with the latest gadgets, tools, technologies, approaches, methods, and practices, and thus, upgrade their performance.

Authors of the workplace learning literature, such as Engestrom $(1999,2001)$, and Lave and Wenger (1991) have always viewed formal education as an inadequate form of learning that only a limited number of working people are able to participate in. This notion is also true in the case of teachers in this country, or many other countries for that matter, because the allocated budget and opportunities for teachers to further their studies or to attend off-site trainings are very limited. Even with larger number of Malaysian teachers involved with such development programmes due to recent updates in the educational policy (National Education Blueprint, 2006-2010) and the national mission (Ninth Malaysia Plan, 2006-2010), the percentage of those who participate in them are still very low as compared to the large population of teachers in this country. This is an endemic situation, experienced by teachers and other workers in general - the need for learning exceeds the opportunity for formal learning.

Thus, researchers began to seek for better ways of improving teachers' learning by steering away from the traditional concept of staff development, for example, to a more participative nature of learning, which focuses more on the way workers are given the opportunity to learn through engaging in activities in their workplaces (Billett, 2001), or similarly, in communities of practice (Lave \& Wenger, 1991).

106 IJMS 17 (2), 105-120 (2010) 


\section{Statement of the Problem}

Growing interest in the role of workplace learning as a significant contributor toward teachers' development, and eventually, their performance, evoked many qualitative studies. Findings from these studies, for example, those of Hodkinson and Hodkinson $(2005,2003)$, Hughes (2004), Lohman (2000, 2003), and Williams (2003) supplied rich information to explain the workplace learning that teachers experience in school. However, there is a scarcity in quantitative data to generalise the status of workplace learning among teachers in school. Among the few, Lohman (2006) tried to gather quantitative data to support her previous qualitative studies (Lohman, 2000, 2003). Other researchers, for example Carter and Francis (2001), and Williams (2003) also ventured into teacher's workplace learning but have limited their focus on the nature of learning by new teachers in their process of adjusting themselves to their new work environment .

Comparatively, more attempts were made in analysing and measuring workplace learning in other contexts, for example those which measured approaches used in learning by employees from different organisations in Canada (Kirby, Knapper, Evans, Allan \& Gadula, 2003), workplace learning strategies among Canadian accountants (Hicks, Bagg, Doyle \& Young, 2007), workplace learning and their relationships with job performance in small US banks (Rowden \& Conine, 2005), and levels of learning (Burgess, 2005; Eraut, 2000). Among these studies, only one study, which was by Kirby et al. (2003), reported on the exploratory factor analysis of the instrument used to measure workplace learning (in this case, approaches used in workplace learning).

The scarce research pertaining to workplace learning among teachers may be due to the lack of valid instrument which can measure this construct in the educational settings.

The purpose of this study was to validate an instrument measuring teachers' engagement in workplace learning activities, the Teacher Engagement in Workplace Learning Scale (TEWLS). Precisely, the study attempted to answer two research questions: 1) Is the TEWLS a reliable instrument?; 2)Does the theoretical-based twofactor measurement model of the TEWLS fit the data collected in the Malaysian secondary school setting?

It was hoped that the validation of the TEWLS would contribute to the theoretical and practical establishment of the concept of workplace learning in the Malaysian school context. 


\section{Review of the Literature}

\section{Conceptualising Workplace Learning}

There are two views on learning approaches which were found to be useful in understanding teachers' learning in the workplace: learning as (co)participation and learning as (re)construction. The former, learning as (co)participation rooted from situated learning theory, which upholds the concepts of legitimate peripheral participation and communities of practice. These two concepts were used to explain how people enter into new communities and learn to gain knowledge and skills which are embedded in the cultural, historical, and situational practices of the communities, so as to be accepted as "full participants" in the respective communities (Lave \& Wenger, 1991). A reciprocal kind of interaction exists between the learner and the community whereby his learning takes place, in a way that the learner is trying to learn by participating in the activities held in the community so as to be accepted, and at the same time, the cultural, historical, and situational practices of the community is constituted by the learner as a member of the society (Billet, 2002, 2004; Fuller, Hodkinson, Hodkidson \& Unwin, 2005).

A critique of this metaphor of learning has highlighted that participation neither focuses on the product nor the process of learning (Hager, 2004). Although the act of participating involves some kind of a process, it describes more of a social process than the learning process, and as far as the actual learning is concerned, it is about gaining insights about the particular community and accumulating characteristics (products of learning) so as to have a sense of belonging to the group or community. At the extreme end, participation in certain closed communities which are not in favour of change or are highly resistant to accepting ideas from resources outside of their close-knitted society, can hamper learning.

Therefore, Hager (2004) suggested that learning as a (re)construction approach as more representative of the actual learning that happens in the workplace. Parallel to Dewey's (1938) and Lewin's (1975) idea of learning, this learning approach explains how learning is as an ongoing process whereby people need to grow and become part of the environment and how learning changes both the learner and his environment (Hager, 2004).

According to Hodkinson and Hodkinson (2005), it is best to combine both approaches of learning. The reason is that both of these literature 
groups are striving to expand the notion of teachers' learning from a purely individual act (acquisition), to one that is concerned with changing the learner through developing and improving (construction), complemented with collaborating with others in the workplace (participation). The idea of merging the two metaphors of learning follows their earlier research findings on the way teachers learn at work (Hodkinson \& Hodkinson, 2003, 2004). By doing so, the authors were actually trying to consider the account of learning by experienced workers, which was mentioned in Fuller et al. (2005), as being neglected by Lave and Wenger (1991), when they focused too much on the learning of novices as newcomers in the communities of practice-nothing on the learning of old timers in new places or the learning of experienced people from the newcomers or the novices.

This new pattern of viewing teachers' learning, from a wider perspective is another way of re-emphasising the importance of individual learning but without losing the social and cultural essence of learning. This is deemed necessary because workplace learning is built upon two important key ideas: (i) workplace learning is ubiquitous, seen as an integral part of workplace practices (Billet, 2001; Engestrom, 2001; Lave \& Wenger, 1991); and, (ii) workplace learning is part of the social and cultural process. Parallel to theorists such as Billett (2001), and Beckett and Hager (2000), the notion that this type of learning as being inferior compared to learning in the formal educational setting is rejected.

\section{Classifications of Workplace Learning}

In terms of the classifications of workplace learning, many authors try to distinguish each type of learning that they label, but often these descriptions were found to be overlapping and interchangeably used in the literature. The clear distinction between formal and informal learning, for example, can be very difficult to determine (McGivney, 1999). The most common terms used in categorising workplace learning are: 1) formal learning; 2) non-formal learning; 3) informal learning; 4) incidental learning.

Formal learning represents off-the-job learning which is provided by education or training institutions, highly structured, intentional, often sponsored, with the presence of an instructor, teacher, or facilitator, and leads to certification (Marsick \& Watkins, 1990, 2003; Clarke, 2005). Such learning is often embedded in activities like seminars, workshops, and courses. The term non-formal learning is less popularly used by authors, but preferred by some. Having categorised workplace learning as either formal or non-formal, Eraut (2000) defined non- 
formal learning as belonging to the opposite end of the formal learning, with contrasting properties, in that they are unintentional, unstructured, non-sponsored, and occurs in the absence of a teacher. Using the same label, the European Commission (2001) defined nonformal learning as having such attributes as also non-sponsored and not leading to any kind of certification, but still structured and intentional. This interpretation of non-formal learning takes the middle point between formal learning and informal learning, with the latter being non-sponsored, no certification involved, unstructured and could be planned or unplanned (Marsick \& Watkins, 1990; European Commission, 2001; Skule, 2004). In theorising informal learning in the workplace, Marsick and Watkins (1990) added another category of learning, namely, incidental learning, which is actually a byproduct of another activity. Obviously, this category of learning is unintentional and highly unstructured. It deals a lot with tacit, hidden, and often taken-for-granted knowledge. Nonetheless, there are also authors, such as Billett (2001), who are totally against any form of categorisation of workplace learning and claimed that to label any learning as informal is erroneous because learning takes place within social organisations or communities which have formalised structure.

Although there are at least four categories of learning as mentioned above, authors do not always include all types of workplace learning in their studies. In fact, many authors narrowed down their scope of workplace learning to a single dimension, usually informal learning. The reason for much focus given to informal learning is because a study by Marsick and Watkins (1990) found that more than $80 \%$ of learning in workplaces is gained through informal learning, as opposed to formal learning. This is supported by many others, such as Eraut (2004), Rowden and Ahmad (2000), and Sorohan (1993).

\section{Operational Definitions}

In the context of this research, not only teachers' workplace learning comprises formal and informal learning, but more importantly, it also takes into consideration the ways in which teachers learn at their workplaces, individually or in group. The inclusion of formal learning (particularly in-service training or courses) is based from the fact that little is known about the contribution of either formal or informal workplace learning in the context of teacher's workplace learning in Malaysia. Thus, excluding either category of learning might not portray the actual workplace learning among teachers in this country. 
The decision to omit incidental learning was to reduce the problems in measuring workplace learning because incidental learning deals a lot more with the explicit knowledge, as opposed to implicit, tacit knowledge. By looking at ways in which teachers learn, individually or in group, it was hoped that this study would be able to add more to the explication of the process by which workplace learning occurs, both from the learning as (re)construction approach and learning as (co)participation approach. In addition, teachers' workplace learning in this study is also viewed as a kind of effort that teachers' venture in order to perform better in their jobs.

Therefore, teachers' workplace learning in this study is defined as teachers' engagement in formal and informal learning activities, either individually or in group, as a form of effort to upgrade their performance.

\section{Methodology}

\section{Instrumentation}

The process of constructing the items for measuring teachers' engagement in workplace learning began with a review of the relevant theory and previous research work. Based on a quantitative study on teachers' learning activities by Lohman (2006), eight items were found to be useful and thus adapted. Most of the learning activities among teachers measured by Lohman were also found to be prominent in the learning of other professions as well (Cheetham \& Chivers, 2001). The other five items were constructed based on a review of informal learning especially by Cheetham and Chivers (2001) and qualitative findings of Hodkinson and Hodkinson (2005). The 13 items were then translated to Bahasa Melayu and back-translated (Brinslin, 1970; Chapman \& Carter, 1979) to ensure the precision of the translation process. In order to check for content validity, personal informal communications were held between the authors and seven school teachers. In addition, two experts in the field were consulted. The questionnaire was also improved in terms of content validity, readability, and reliability by pilot testing it among 35 schoolteachers.

The final Teacher Workplace Learning Scale (TEWLS) consisted of 13 items, scored on a five-point Likert-type scale, with nine items measuring individual workplace learning engagement and four items measuring group workplace learning engagement. Sample items for individual and group learning activities are "I put effort to do my 
job better by observing others or role modelling" and "I put effort to do my job better by working alongside junior or senior colleagues", respectively.

\section{Participants}

The sample in this study involved 500 secondary school teachers in northern Malaysia, who were selected through a multistage cluster sampling procedure (Ary, Jacobs \& Razaveih, 2002). Data were gathered through a survey, a research method appropriate for model testing which requires a large pool of data of $n \geq 200$ (Bryne, 2005). A total of 478 teachers returned the questionnaire whereby 470 were found to be usable for data analyses. Of the total 470 respondents, $66.2 \%$ were female, while the remaining $33.8 \%$ were male teachers, aging 21 to 54 years old $(\underline{\mathrm{M}}=.37 .8, \mathrm{SD}=6.34)$. Their experience as school teachers ranged from 2 to 30 years $(\underline{M}=12.8, S D=6.04)$.

\section{Data Analyses}

Reliability of the instrument was established through the observation of internal consistency (Cronbach's alpha), whereas construct validity was checked by means of an exploratory factor analysis (EFA) with principal axis factoring and obique (direct oblimin) rotation. These analyses were carried out via Statistical Packages for Social Sciences (SPSS) version 14.0 software (SPSS, 2007). The analyses were then followed by a confirmatory factor analysis via Analysis of Moment Structure (AMOS) version 7.0 (Arbuckle, 2006).

\section{Results}

\section{Reliability}

Means, standard deviations, and reliabilities of the TEWLS are shown in Table 1. Cronbach $\alpha$ were .82 and .86 for engagement in individual and group learning activities, respectively. For the overall measurement of teachers' engagement in workplace learning activities, the $\alpha$-value was .87, which was greater than .70 (Guilford, 1956), thus establishing reliability of this instrument. Tests of "alphaif-item deleted" did not indicate substantial improvement of the reliability by deleting any item. Further analysis of the items in each construct witnessed that the corrected item-total correlations were above the cut-off point of .30 (Nunnally, 1978) for all items in both of the constructs, indicating preliminary evidence of convergent validity for the two constructs. 
Table 1

Means, Standard Deviations, and Reliabilities of the TEWLS

\begin{tabular}{lccc}
\hline & $\begin{array}{c}\text { Engagement } \\
\text { in individual } \\
\text { workplace } \\
\text { learning } \\
\text { activities } \\
(9 \text { items })\end{array}$ & $\begin{array}{c}\text { Engagement in } \\
\text { group } \\
\text { workplace } \\
\text { learning } \\
\text { activities } \\
(4 \text { items })\end{array}$ & $\begin{array}{c}\text { Overall } \\
\text { engagement } \\
\text { in workplace } \\
\text { learning activities } \\
(13 \text { items) }\end{array}$ \\
\hline Mean & 3.92 & 4.20 & 4.01 \\
Standard deviation & .41 & .46 & .39 \\
Reliability $(\alpha)$ & .82 & .86 & .87 \\
\hline
\end{tabular}

\section{Exploratory Factor Analysis}

Results on the exploratory factor analysis (EFA) indicated that two factors emerged as having eigenvalues of greater than 1 . Nine items loaded on the first factor, whereas the rest of the other four items loaded on the second factor. There were no substantial cross-loading and the loading coefficient for each item was above the cut-off point of .30, the lower bound for an item to be retained (Comrey, 1973; Nunnally, 1978). The results provided initial evidence of the proposed twofactor measurement model for engagement in workplace learning, which comprises two facets: i) individual workplace learning; and, ii) group workplace learning.

\section{Confirmatory Factor Analysis}

All items were submitted to a confirmatory factor analysis to test the second order measurement model of engagement in workplace learning. The fit indexes (comparative fit index: CFI, Tucker-Lewis index: TLI, root mean residual: RMR, root mean square error of approximation: RMSEA, and chi-square/degree of freedom: $\chi^{2} / \mathrm{df}$ ) were examined for this measurement model to test its fitness to the data collected in this study.

Good-fitting model was established with TLI $=.92, \mathrm{CFI}=.94$, RMSEA $=.068$ (with $90 \%$ confidence interval of $.058-.079)$, RMR $=.019$, and $\chi^{2} / \mathrm{df}=3.19\left(\chi^{2}=204.26, \mathrm{df}=64\right)$. The loadings ranged from $\beta$-values of .53 to .97 and were all significant at $p<.05$, $t$-value ranged from 8.89 to 18.26 . The results provided evidence for convergent validity 
and construct validity of the instrument used. In other words the TEWLS was proven a valid measure and a useful two-factor model for explaining teachers' engagement in workplace learning activities. Figure 1 illustrates the measurement model with all the parameter estimates.

Table 2

Factor Loadings for Exploratory Factor Analysis with Principal Axis Factoring and Direct Oblimin Rotation

\begin{tabular}{|c|c|c|}
\hline \multirow{2}{*}{ Items } & \multicolumn{2}{|c|}{ Factor Loadings } \\
\hline & $\begin{array}{c}\text { Factor } 1 \\
\text { (Engagement in } \\
\text { individual } \\
\text { workplace learning } \\
\text { activities) }\end{array}$ & $\begin{array}{c}\text { Factor } 2 \\
\text { (Engagement in } \\
\text { group } \\
\text { workplace learning } \\
\text { activities) }\end{array}$ \\
\hline Workplace learning 3 & .700 & \\
\hline Workplace learning 5 & .688 & \\
\hline Workplace learning 2 & .623 & \\
\hline Workplace learning 6 & .611 & \\
\hline Workplace learning 7 & .609 & \\
\hline Workplace learning 4 & .504 & \\
\hline Workplace learning 8 & .444 & \\
\hline Workplace learning 9 & .389 & \\
\hline Workplace learning 1 & .340 & \\
\hline Workplace learning 11 & & .855 \\
\hline Workplace learning 12 & & .813 \\
\hline Workplace learning 10 & & .733 \\
\hline Workplace learning 13 & & .691 \\
\hline Total Eigenvalues & 5.39 & 1.35 \\
\hline Percentage of variance explained & 37.40 & 6.58 \\
\hline $\mathrm{KMO}$ & .91 & \\
\hline Bartlett's test of sphericity/df & $* * 2266.915 / 78$ & \\
\hline Total variance explained & 43.98 & \\
\hline
\end{tabular}

114 IJMS 17 (2), 105-120 (2010) 


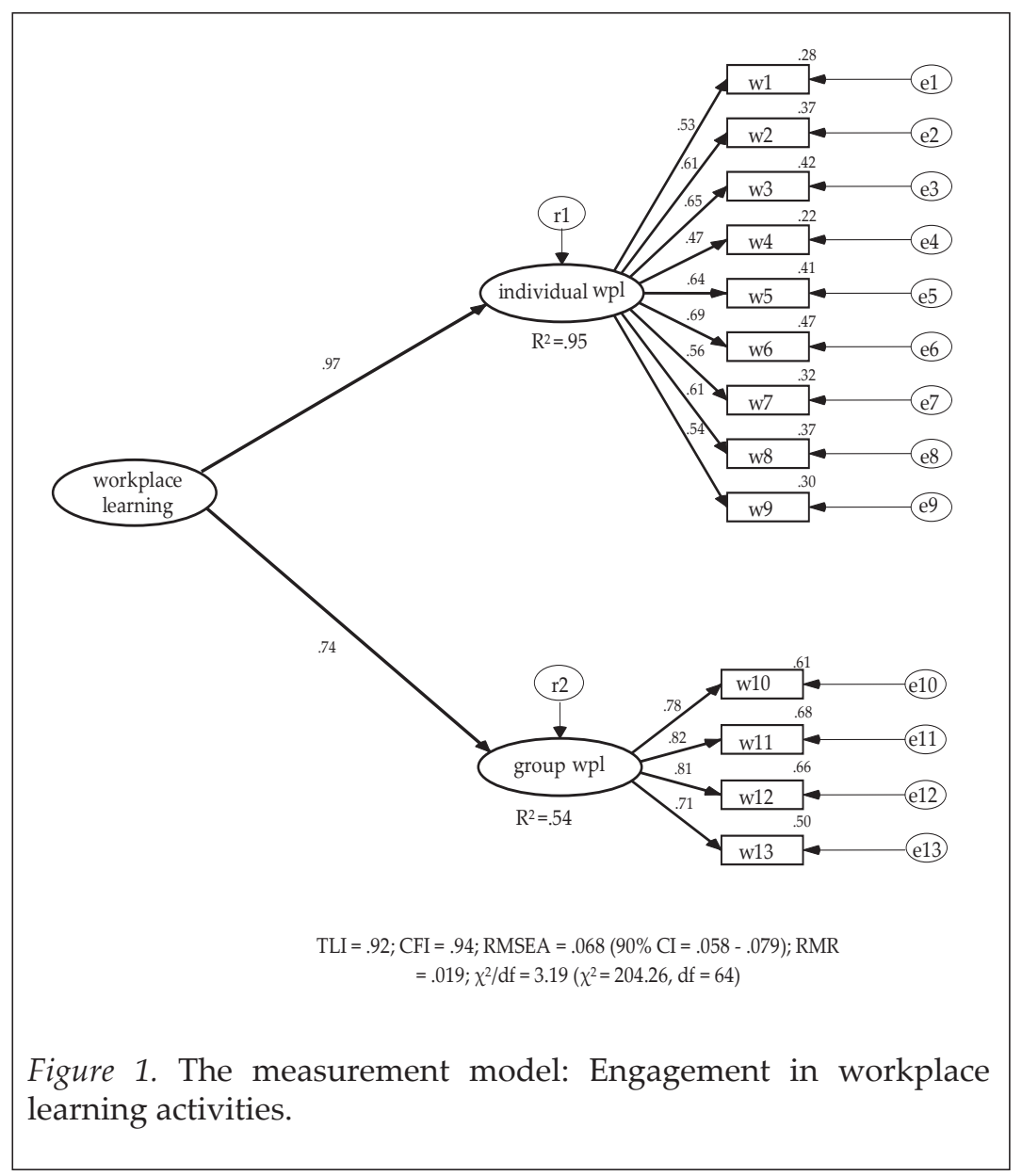

\section{Discussion}

Based on the literature review and findings of previous research, a two-factor model was proposed and tested for the measurement of engagement in workplace learning activities, encompassing two ways by which teachers' learn (individually or in group) in order to perform better in their jobs. The decision to model teachers' workplace learning by the way they choose to be engaged in (individually or in group) is parallel to the idea of conceptualising workplace learning as a combination of a (re)construction and (co)participation approaches (Hodkinson \& Hodkinson, 2005). Individual learning is seen as more of a (re)construction process whereby teachers' as adult learners continuously generate knowledge from their own (or other people's) 
tacit knowledge and experiences. On the other hand, group learning becomes a (co)participation process which is an adaptive strategy used by teachers when they try to gain and share knowledge by collaborating with others.

Findings on test of the measurement model indicated that the learning activities did load into the designated factors. The activities which fall into the individual learning category are role-modeling, reading, tackling challenges in carrying out job tasks, supervising/mentoring/ coaching, trying out new ideas, reflecting, searching for material on the Internet, taking part in a society, and attending meetings/courses/ forums/seminars. As for group learning, this includes learning with others by cooperating in group work during courses or training sessions, working alongside other teachers in school, sharing materials and exchanging views with students or colleagues. From the findings, it is important to highlight that individual learning is not confined to activities which result from teachers learning alone by themselves but also when they learn from others. Thus, both kinds of workplace learning activities do involve a certain level of social interaction among the teachers and critical reflections within the individual teacher. These will enable to effectively transform the tacit knowledge accumulated in them into explicit knowledge which can be shared among them.

The activities examined in the present study were also indicated as relevant to workplace learning experience of workers, specifically teachers, in the previous studies (Eraut, 2000; Hodkinson \& Hodkinson, 2005; Lohman, 2000, 2003, 2006); and also the learning of other professionals (Cheetham \& Chivers, 2001). The present study did not only support the findings of the above previous work, but additionally, it enhances the validity of the instrument measuring teachers' engagement in those learning activities by introducing a two-factor model which surpassed a confirmatory factor analytic test. In other words, the findings in the present study add to the literature by proposing a valid measure for engagement in workplace learning activities among school teachers. The measure can be an important tool for research and practice in topics related to teachers' learning and development.

There are several limitations of this study. Firstly, the study depended on self-report measures of engagement in workplace learning activities. This often creates concerns in terms of common method variance, particularly bias yielding from respondents' social desirability factor. Secondly, the data was cross-sectional data -

116 IJMS 17 (2), 105-120 (2010) 
collecting longitudinal data is preferable for model-testing. An additional limitation of this study is the use of the same data for both exploratory and confirmatory factor analysis.

\section{Conclusion}

In conclusion, the present study addressed the problem of field research into the topic of workplace learning among school teachers by producing a valid measure of engagement in workplace learning activities. The next important step is to replicate the findings of this study using other samples of teachers in the secondary schools and of other educational settings such as the primary schools, colleges, and universities. Such replication will provide generalisability of the measure to other samples in this country and perhaps even in other countries.

In order to further enhance the validity of the instrument, research should also include a criterion variable to test the predictive validity of engagement in workplace learning activities. Outcome variables such as job performance, teacher competence, and teacher efficacy are among the criterion variables which could possibly be influenced by teachers' engagement in workplace learning activities.

\section{References}

Arbuckle, J. L. (2006). Amos (Version 7.0) [Computer Software]. Chicago: SPSS.

Ary, D., Jacobs, L. C., \& Razaveih, A. (2002). Introduction to research in education (6th ed.). Belmont, CA: Wadsworth/Thompson Learning.

Beckett, D., \& Hager, P. (2000). Making judgments as the basis for workplace learning: Towards an epistemology of practice. International Journal of Lifelong Education, 19, 300-311.

Billett, S. (2001). Learning through work: Workplace affordances and individual engagement. Journal of Workplace Learning, 13, 209214.

Billett, S. (2002). Crittiquing workplace learning discourses: Participation and continuity at work. Studies in Education of Adults, 34, 56-67.

Billett, S. (2004). Workplace participatory practices: Conceptualising workplaces as learning environments. Journal of Workplace Learning, 16, 312-324. 
Brinslin, R. W. (1970). Back-translation for cross-cultural research. Journal of Cross-cultural Psychology, 1, 185-216.

Bryne, B. (2005). Factor analytic models: Viewing structure of an assessment instrument from three different perspectives. Journal of Personality Assessment, 85, 17-32.

Burgess, D. (2005). What motivates employees to transfer knowledge outside their work unit? Journal of Business Communication, 42, 324-348.

Carter, M., \& Francis, R. (2001). Mentoring beginning teachers' workplace learning. Asia-Pacific Journal of Teacher Education, 29, 249-262.

Chapman, D. W., \& Carter, J. F. (1979). Translation procedures for the cross cultural use of measurement instrument. Educational Evaluation and Policy Analysis, 1, 71-76.

Cheetham, G., \& Chivers, G. (2001). How professionals learn in practice: An investigation of informal learning amongst people working in professions. Journal of European Industrial Training, $25,248-292$.

Clarke, N. (2005). Workplace learning environment and its relationship with learning outcomes in healthcare organisations. Human Resource Development International, 8, 185-205.

Comrey, A. L. (1973). A first course in factor analysis. New York: Academic Press.

Dewey, J. (1938). Experience and education. New York: Collier Books.

Engestrom, Y. (1999). Activity theory and individual and social transformation. In Y. Engestrom, R. Miettinen, \& R. Punamaki (Eds.), Perspectives on activity theory. Cambridge: Cambridge University Press.

Engestrom, Y. (2001). Expansive learning at work: Towards an activity-theoretical reconceptualisation. Journal of Education and Work, 14, 133-156.

Eraut, M. (2000). Non-formal learning and tacit knowledge in professional work. British Journal of Educational Psychology, 70, 113-136.

European Commission (2001). Communication from the commission: Making a European area of lifelong learning a reality. Retrieved from http://www.bologna-berlin 2003.de/pdf/Mitteilung Eng. pdf

Fuller, A., Hodkinson, H., Hodkinson, P., \& Unwin, L. (2005). Learning as peripheral participation in communities of practice: A reassessment of key concepts in workplace learning. British Educational Research Journal, 31, 49-68.

Guilford, J. P. (1956). Psychometric methods. New York: McGraw-Hill.

118 IJMS 17 (2), 105-120 (2010) 
Hager, P. (2004). Conceptions of learning and understanding learning at work. Studies in Continuing Education, 26, 3-17.

Hicks, E., Bagg, R., Doyle, W., \& Young, J. D. (2007). Canadian accountants: Examining workplace learning. Journal of Workplace Learning, 19, 61-77.

Rowden, R. W., \& Conine, C.T. Jr. (2005). The impact of workplace learning on job satisfaction in small US commercial banks. Journal of Workplace Learning, 17, 215-230.

Hodkinson, H., \& Hodkinson, P. (2004). Rethinking the concept of community of practice in relation to schoolteachers' workplace learning. International Journal of Training and Development, 8, 21-31.

Hodkinson, H., \& Hodkinson, P. (2005). Improving school teachers' workplace learning Research Papers in Education, 20, 109-131.

Hodkinson, P., \& Hodkinson, H. (2003). Individuals, communities of practice and the policy context: School teachers' learning in their workplace. Studies in Continuing Education, 25, 3-21.

Hughes, C. (2004). The supervisor's influence on workplace learning. Studies in Continuing Education, 26, 275-287.

Kirby, J. R., Knapper, C. K., Evans, C. J., Allan, E. C., \& Gadula, C. (2003). Approaches to learning at work and workplace climate. International Journal of Training and Development, 7, 31-52.

Lave, J., \& Wenger, E. (1991). Situated learning. Cambridge: Cambridge University Press.

Lewin, K. (1975). Field theory in social science selected theoretical papers. Westport: Greenwood Press.

Lohman, M. C. (2000). Environmental inhibitors to informal learning in the workplace: A case study of public school teachers. Adult Education Quarterly, 50, 83-102.

Lohman, M. C. (2003). Work situations triggering participation in informal learning in the workplace: A case study of public school teachers. Performance Improvement Quarterly, 16, 40-54.

Lohman, M. C. (2006). Factors influencing teachers' engagement in informal learning activities. Journal of Workplace Learning, 18, 141-156.

Marsick, V. J., \& Watkins, K. E. (1990). Informal and incidental learning in the workplace. London: Routledge.

Marsick, V. J., \& Watkins, K. E. (2003). Demonstarting the value of an organisation's learning culture: The dimensions of the learning organisation questionnaire. Advances in Develping Human Resources, 5, 132-151.

McGiyney, V. (1999). Informal learning in the community and development: A tringger for change and development. Leicester: National Institute of Adult continuing Education. 
National Education Blueprint, NEB. (2006-2010). Retrieved from http://www.moe. gov.my/tayang.php? laman=pipp\&unit=kem enterian\&bhs=en

Ninth Malaysian Plan (2006-2010). Retrieved from http://www.epu. gov.my/ rm9/html/english.htm

Nunnally, J. C. (1978). Psychometric theory (2nd ed.). New York: McGraw Hill.

Rowden, R. W., \& Ahmad, S. (2000). The relationship between workplace learning and job satisfaction in small to mid-sized business in Malaysia. Human Resource Development International, 3, 307-322.

Skule, S. (2004). Learning conditions at work: A framework to understand and assess informal learning in the workplace. International Journal of Training and Development, 8, 8-20.

Sorohan, E. (1993). We do, therefore we learn. Training and Development, $4,47-52$.

SPSS Inc. (2007). SPSS for Windows (Version 14.0) [Computer Software]. Chicago: SPSS Inc.

Williams, A. (2003). Informal learning in the workplace: A case study of new teachers. Educational Studies, 29, 207-219. 